\title{
The Politeness Value of the Characters Srikandi and Dewi Kunti in the Mahabarata Epic by Rajagopalachari
}

\author{
Ulfa Tursina ${ }^{1, *}$, Sahid Teguh Widodo ${ }^{2}$, Sidhiq Hidayatulloh ${ }^{3}$ \\ ${ }^{1,3}$ Universitas Sebelas Maret, Surakarta, Indonesia \\ ${ }^{2}$ University Centre of Excellencece Javanology for Javanese Tradition, Universitas Sebelas Maret, Surakarta \\ Indonesia \\ *Corresponding author. Email: fafaulfatursina13@gmail.com
}

\begin{abstract}
This research describes the form of politeness and character of the characters Srikandi and Dewi Kunti in the epic Mahabarata Rajagopalachari. Srikandi is a brave puppet character, while Dewi Kunti is a wise mother puppet character. Srikandi and Dewi Kunti are female characters in wayang who have the same strength as men. This study uses a qualitative descriptive method with a feminist approach. The results of this study show how the form and character and gender relations of the characters Srikandi and Dewi Kunti in the wayang story. Second, this study found the feminist characters of the two characters based on their attitudes and ways of responding to various problems in the story.
\end{abstract}

\section{Keywords: Feminism Values, Kunti, Mahabharata, Rajagopalachari, Srikandi}

\section{INTRODUCTION}

Most of the ancient manuscripts absorb Sanskrit. That is, literary texts contain various forms of instructions or guidelines. Why, the element of the word "sas" has the meaning of instruction or it can also be interpreted freely as doctrine. Meanwhile, the word "tra" means a tool or means. And, "su" in the word literature means "right" [1].

A literary work was created not without purpose [2]. Literary works sometimes rely on the realities of everyday life, such as social, cultural, and even gender issues. Many poets take women's themes in their literary works, which are called feminist literary works. This feminist academic work sometimes cannot give a position for women, so they have to jump over the thoughts of women's own social life. This has led to scientific criticism of feminism and research that applies literary criticism to feminism.

Feminism academic comments appear to review, study, study, give consideration and provide an assessment of the advantages and disadvantages of literary works. The literary study of feminism can be interpreted as a study that looks at literature with a unique awareness, realizing that there is a gender that has a lot to do with our culture, literature, and life.
This gender makes the difference between all of them that also makes a difference to the author, the reader, the character and the external factors that influence the situation of corals making up [3]. At the heart of feminism, the goal is to improve women's standing to be equal or aligned with men's character. Feminism's struggles and efforts to achieve these goals are in many ways. One way is to obtain the same rights and opportunities that men have [4].

There are many female characters in puppets, such as Banowati, Sarpakenaka, Srikandi, and Dewi Kunti. Banowati is a female puppet figure who has a dominant personality, appears to her to be vicious. She also has a firm stance on the establishment. Sarpakenaka is a negative figure of female puppets. The dominant character in her is incredibly fierce, grumpy, and even snapping. And she is challenging to be convinced. To anyone, she is always negativeminded and likes to criticize.

Srikandi is a puppet character who is brave, loud, and skilled in darts. Her name is passionate and confident. Sometimes she also moves spontaneously out of curiosity. She is a fascinating woman, especially in the fight for the truth. At the same time, Dewi Kunti is a wise mother puppet figure who has a high dedication to educating and guiding Pandawa, a 
symbol of the superior generation. Kunti's model deserves and is remembered as a mother who managed to educate a generation, a mother who is in nature's corridors, and plays a nationality and country role. The reason for choosing Srikandi and Dewi Kunti because they are female characters in puppets with the same power as men. From this description, this research discusses how gender relations in Srikandi and Dewi Kunti's strength in tools, and how feminist patterns are based on the solidity of Srikandi and Dewi Kunti.

\section{MATERIAL AND METHODS}

This research is included in a multidisciplinary research model. The form of research chosen is descriptive qualitative because it is considered very appropriate and able to provide a complete picture [10] [11] [12] [13]. The second reason is based on the characteristics of the research problem, data sources, and research data [14]. The data in this study were collected and analyzed using three-component interactive work methods, namely data reduction, data presentation, and verification [15]. The strategy chosen in this research is a single case study strategy focused on the subtle and polite characters of Srikandi and Dewi Kunthi. Data collection techniques used content analysis and interviews [16]. Data analysis technique is an interactive model data analysis technique that moves between three components of analysis which include data reduction, data presentation, verification and conclusion.

\section{FINDINGS AND DISCUSSION}

\subsection{Gender Relations in Srikandi and Dewi Kunti's Pent-up on Puppets}

In puppet stories (Mahabarata and Ramayana) synonymous with war stories. In this war, leaders or knights are discussed as having the value of politeness in attitude and language, so this is what brings victory in terms of politics or war. In the realm of Indonesian culture, knights are usually identical with male figures. Men are depicted as strong and wise, to the point that men are higher than women. Women are considered to be the number two people born in the world. During the colonial period in ancient Indonesia, women were considered human beings who could only live in the house and kitchen and only purify male sexuality. Therefore, the movement sees the need to uphold equal position, rights, obligations, and roles between men and women [5].

But the above description was not accurate; sometimes, women could be substantial, thoughtful, and respected leaders. The number of stories about female knights seemed to have opened up doubts about the woman's actual figure. One of the famous female knights was the story of Srikandi's leadership. Srikandi participated in the war against Bhisma in the Baratayudha war; she was elected as Senapati leading his soldiers against Bhisma's army. She was the only woman to participate in the action in the puppet story. Srikandi also learned archery to protect his country from Prabu Jungkungmardeya attacks. Besides, Kunti could also play a double role as a father and mother. After her husband, Prabu Pandu, Kunti became the family's head, educating her sons into a superior generation. Kunti performed her role as a father without forgetting her role as a woman who also became a mother. The two women's figure was one of the rebuttals that previously mentioned that men were superior to women.

From the above statement, the analysis of gender relations located in the puppet figures of Srikandi and Dewi Kunti laid in the power relationship held by men and women. The word 'power' was not a Power that was defined as a set of institutions and devices that guaranteed citizens' compliance in a particular country. The researcher's power was described as a force in one's own right to do everything (lead). The emphasis here was initially the history of women who were always oppressed and tainted by men. From men's actions towards women, it would give rise to the power within women to sue. In this case, the power came from within the woman, who then came up with the term power. There was no denying that there was truth in him, which is the basis of fact, was knowledge. Knowledge gradually became a discussion in the community that would form a discourse. Discourse meant something written, said, or communicated using signs and marks other relationships with structuralism and its dominant focus on language. Thus, power was always directly proportional to knowledge, and knowledge was related to discourse, so that between expertise, address, and passion was still in relational.

For example, Srikandi, who dared to participate in the war, was good at archery and a defender of the truth. It all started when Srikandi was going to be married to Prabu Jungkunmardeya, but she refused. Because Srikandi refused, his country was destroyed by Prabu Jungkunmardeya. Finally, Srikandi desired to learn archery with Arjuna to fight Prabu Jungkunmardeya to defend his country. Srikandi's knowledge of archery finally gave rise to discourse in society that it did not have to be the male side that could shoot. Archery knowledge was not a knowledge that only men had; women also had it. In today's example, many obstetricians come from men. But it has been in the context of women all this time. This happens because of the power within a person to 
learn about the womb's science that is synonymous with women. That power would bring forth knowledge in her. Gradually this began to appear to the public and was widely talked about by the public. Different cultures also influenced gender differences in other countries that produced local wisdom.

Dewi Kunti's role as a single mother was to educate her children into a quality generation. At that time, Dewi Kunti planned to escape from the palace along with the Pandawas. Dewi Kunti deliberately made a festive party so that the guards fell asleep because of the satiety. In the middle of the night, Bima burned down the palace, and soon they entered through a secret tunnel, as in the following excerpt.

"That day, Dewi Kunti threw a festive party for the guards. He said, "My People! In the middle of the night, Bima burned down the palace. The goddess Kunti and the Pandawas have escaped through a secret tunnel". [6]

From the above quote, Dewi Kunti was a brave and patient woman. In addition to her beauty, Dewi Kunti is a stoic woman who became a single mother raising her five sons.

This indicated that there was gender equality between husband and wife. Gender equality between husband and wife laid in the division of their respective duties. The husband acted as the head of the household and a vital protector for his wife and children. He guaranteed livelihood and became a strong supporter of his family, while women acted as a wife and mother taking care of her husband and children's needs. The role of a mother was as a family center. It generally held finances and was quite decisive in making important decisions in the family. In terms of educating children, father and mother roles were very influential so that their children grew up entirely and succeeded. But the mother became the novice teacher who put the primary color on her sons' white sheets.

\subsection{Feminist Pattern Based on Srikandi and Dewi Kunti's Strengths}

Feminism had always been the fast-growing movement for equality in the West, while the cultural forms of feminism in each region were not the same. Like feminism in the east, especially Java, it was not the same as the western form of feminism. Feminism in the West stemmed from women's disappointments; women demanded their rights as whole men, such as in work, sports, war, or government. It was because women only became workers without wages at home and bear all the poor's lives. While eastern women, especially Javanese, were portrayed with a character who surrendered, they undergo a wife's role by parenting while arranging the household. Even more so, amid various responsibilities, in certain conditions, Javanese women were also able to replace husbands. They were also known to be the backbone of the family economy.

In the strengths of Srikandi and Dewi Kunti there was also feminism. Srikandi was an appreciated female character for performing the role commonly played by men. She was the only woman who participated in the war because she was good at archery. She also often defended the truth.

Srikandi is the daughter of Prabu Drupada and Dewi Gandawati. She was nicknamed as the powerful woman for being a perfect role model for a female soldier. Also, she was in charge of Madukara's safety and security. During the Bharatayuda war, Srikandi, as a Pandawa war Senapati replaced Resi Seta. She, with Hrusangkali arrows, killed Bhisma.

The battle between Arjuna and Bhisma took place on Kurukshetra battlefield. Srikandi was a female figure who had a knighthood. Bhisma had principles that he would not fight a woman under any circumstances. Therefore, Srikandi gave Arjuna a chance to defeat Bhisma.

"On Kurusetra's battlefield with Srikandi as a kusir, Arjuna attacked Bhisma. Bhisma knew Srikandi was born female. In accordance with the manners of a knight, bhisma would not fight a woman, under any circumstances. Thanks to Srikandi, Arjuna was able to fight and defeated Bhisma". [6]

Thus, Srikandi became familiar and often used to express a heroic, passionate, and unyielding woman in striving for progress and spreading benefits. Senada [7] in his research that the moral values of srikandi figures are: (a) the value of the spirit of abstinence, (b) the value of courage and responsibility, (c) the value of respect and mutual respect, (d) the amount of reality and science of the people, and (e) the value of aesthetics.

While Dewi Kunti was a mother figure, who could also become a father, she raised and educated her children alone to become a superior generation. The history of Dewi Kunti was known as the mother of Pandawas [8]. Sura or King Suraseno was Sri Krishna's grandfather, who was a descendant of the Yadewa people. King Suraseno had a son named Pritha, famously beautiful and virtuous. Then King Kuntibhoja (Suraseno's cousin) adopted Pritha because he had no children. At that time, the name Pritha since adopted was changed by King Kuntibhoja to Kunti. The following excerpt illustrates Dewi Kunti. 
"Sura, Sri Krishna's grandfather, was an honorable descendant of the Yadwa dynasty. Her daughter, Pritha, is known for her beauty and kindness. Because his cousin Kuntibhoja had no children, Sura gave Pritha to be adopted. Since then, Pritha has been known as Dewi Kunti, following the name of her adoptive father". [6]

The footage explains that Dewi Kunti, who had a female gender, was a descendant of royalty. Vertically the lineage of Dewi Kunti was located above (honorable). Although adopted by others, the horizontal line would be parallel to the Yadwa people. The woman depicted in Kunti explained that position or equality was high. One day in the town of Ekackra, the Pandawas disguised themselves as requesters ask on the street. They hid as Brahmins - the results they obtained to give to his mother. Dewi Kunti was anxious if they come home late, with the following quote.

"In the City of Ekackra, the pandavas disguised themselves as brahmins. They're be asking for it on the streets. They bring what they get for their mother. If mer eka is late to go home, the goddess kunti becomes anxious, afraid if they are struck by catastrophe". [6]

The maternal sense is shown by Dewi Kunti, who worried about the Pandawas disguised as Brahmins. This was seen in the anxiety felt by Dewi Kunti when the Pandawas got calamity in Ekackra City.

From the above exposure, it can be analyzed that Javanese feminism based on the solidity of Srikandi and Dewi Kunti entered into the pattern of Liberal Feminism; this was because liberal feminism aimed to form a harmonious society based on the principle of equality. Liberal feminism arose from liberal political theories that initially opposed discrimination against women regarding legislation, such as equal voting and property ownership. Liberal feminism says that all good men are women created with equal rights. Liberal feminism seeks legislative overhaul to gain educational rights, property rights, birth control, divorce, employment, and suffrage [9]. In principle, liberal feminism wanted women to be given equal opportunities in economic and political terms and related to Srikandi's story of his ability to shoot and participate in warfare and his role in defending his country. This indicates that women could also participate in government, especially politically, so Dewi Kunti could be a mother and father.

Male superiority over women was severed by Kunti's actions that could replace the patriarchal system in which men usually acted as head of the household. Kunti proved it by replacing the head of the family, namely educating and raising her sons to become a superior generation. The feminism pattern was to equalize women over men, but researchers leaned more toward a more comfortable design of liberal feminism than others. Besides, the liberal feminism pattern was the most closely related to the Srikandi and Kunti stories above.

\section{CONCLUSION}

Based on the discussion in this paper, the author drew some of these the following conclusion:

In the politeness of society, we can see the use of everyday language. One of the connections, namely feminist literary theory, is the women's movement which demands a contrast with men. This is one of the traditions that has contributed a lot to the development of cultural studies. Feminist literature is rooted in an understanding of women's inferiority. The simple meaning of feminist literature is looking at literary works with a certain awareness, the awareness that gender has much to do with culture, literature and our lives. Gender is what differentiates between all of them which is also a differentiator for authors, readers, conversations, and external factors that influence the situation of coral formation [3].

How to apply feminist literary criticism in researching an academic work according to Soenardjati Djajanegara is as follows: (1) Identifying one or more female figures found in a literary work, (2) Seeking the status or position of the female figure in society, (3) Identifying the purpose of life of the female figure in the community, (4) Paying attention to what is thought, done, and said by the female models.

In The Epic of Mahabarata C. Rajagopalachari, Srikandi was a brave, loud, and skilled figure in the arrows' process. Her character was passionate and confident. She was a fascinating woman, especially in the fight for the truth. At the same time, Dewi Kunti was a wise mother figure who had a high dedication to educating and guiding Pandawas, a symbol of the superior generation. Kunti's figure deserved to be remembered as a mother figure who managed to educate a generation. She was also a mother who still naturally played a role in nationality and country. Srikandi and Dewi Kunti were female figures who had the same power as men.

\section{REFERENCES}

[1] Ratna, N.K. (2005). Sastra dan Cultural Studies. Yogyakarta: Pustaka Pelajar.

[2] Hastuti, H. B. P. (2011). Laku Dramatis Tiga Tokoh Perempuan dalam Cerpen Lelaki dengan 
Bibir Tersenyum (Sebuah Kajian Feminis). Kajian Linguistik Dan Sastra, 23(1), 30-41.

[3] Sugihastuti. (2005). Teori dan Apresiasi Sastra.Yogyakarta: Pustaka Pelajar.

[4] Djajanegara, S. (2000). Kritik Sastra Feminis: Sebuah Pengantar. Jakarta: Gramedia Pustaka Utama.

[5] Fadlan. (2011). Islâm, Feminisme, Dan Konsep Kesetaraan Gender Dalam Al-Qur' Ân. Karsa, 19(2), 105-119.

[6] Rajagopalachari, C. (2012). Kitab Epos Mahabarata. Jogjakarta: IRCiSoD.

[7] Setyowati, H. (2013). Representasi Feminisme Srikandi Dalam Pertunjukan Wayang Orang Lakon Bisma Gugur. Catharsis: Journal of Arts Education, 2(2), 27-33.

[8] Ariani, I. (2016). Feminisme Dalam Pergelaran Wayang Kulit Purwa Tokoh Dewi Shinta, Dewi Kunti, Dewi Srikandi. Jurnal Filsafat, 26(2), 272-290.

[9] Idris, N. (2010). Fenomena , Feminisme Dan Political Self Selection. Jurnal Wacana, 13(1), 116-131.

[10] Charmaz, K. (2000). Experiencing chronic illness. Handbook of social studies in health and medicine, 277-292.

[11] Strauss, A., \& Corbin, J. (1998). Basics of qualitative research techniques. Thousand Oaks, CA: Sage publications.

[12] Merriam, S. B. (2008). Adult learning theory for the twenty-first century. New directions for adult and continuing education, 2008(119), 9398.

[13] Wibowo, A.H., Ali, M.N.S., Salim, N.A.M., \& Mohamad, B. (2019). The texture of Indonesian story texts in teen literature. International Journal of Innovation, Creativity and Change, 5(2), 1021-1041.

[14] Marohaini, Y. (2004). Penyelidikan kualitatif: Pengalaman kerja lapangan kajian. Kuala Lumpur: Penerbit Universiti Malaya.

[15] Miles, M. B., \& Huberman, A. M. (1994). Qualitative data analysis: An expanded sourcebook. SAGE.

[16] Yin, R. K. (2009). How to do better case studies. The SAGE handbook of applied social research methods, 2, 254-282. 